\title{
A NeW ZEALANDER'S COMMENTS ON AMERICAN LEGAL EDUCATION
}

\author{
R O McGechan*
}

As a visitor among you asked to write down my views on American legal education, I must first tell you, thanking Dean Prosser, of the timely warning contained in a snippet posted in the Faculty Lounge at Harvard on the very first day I spent there; though I was, to be sure, given to understand that it had no personal application. The snippet read:

If any pilgrim monk come from distant parts, if with wish as a guest to dwell in the monastery, and will be content with the customs which he finds in the place, and do not perchance by his lavishness disturb the monastery, but is simply content with what he finds, he shall be received, for as long as a time as he desires. If, indeed, he find fault with anything, or expose it, reasonably, and with the humility of charity, the Abbot shall discuss it prudently, less perchance God had sent him for this very thing. But, if he have been found gossipy and contumacious in the time of his sojourn as guest, not only ought he not to be joined to the body of the monastery, but also it shall be said to him, honestly, that he must depart. If he does not go, let two stout monks, in the name of God, explain the matter to him.

I shall do my best to lend ear to this wisdom from Saint Benedict, the more so even because friends in the United States urged me to be critical. They would have me bring to you the freshness, as they so generously put it, of an outsider's point of view. I protest that you have developed so much variety in point of view that you have already anticipated all I can say; but even when I have said that, they would still have me critical.

\section{TECHNICAL ASSISTANCE AND INSPIRATION}

I spent six months in the United States and Canada, visiting in many law schools. This was made possible by the Carnegie Corporation and the American Educational Foundation in New Zealand. My purpose was to see your teaching methods at first hand so that if possible I might, guided by the light of your very full experience and attainments, develop in New Zealand methods suitable to our conditions and needs. Naturally I took a keen interest in many other aspects of the American law school, academic and administrative - its

* Professor and Dean of Law, Victoria University College, New Zealand. The paper was first published at (1953) 5 Journal of Legal Education 286. 
relationship to the profession, to the courts and to the community. I enjoyed it all immensely, have a great deal to tell, and, now back home once more, a great deal to do.

I am not going to write of New Zealand legal education, but I would like at the very outset of this article to mention some changes we have made or are making at the Law School at Victoria University College as the direct result of the first-hand knowledge of American schools and their methods we have now acquired. First, we have begun to experiment with case method. In this, of course, we are not building on nothing. I had for years seldom merely lectured; I had combined discourse from the teacher with an open invitation to the class to question and criticise anything said and to raise issues for discussion; there had always been some discussion and very often as much and even more than in some of your classes. But we had not used case method as such, though to be sure we often thrashed out cases in class, not as illustrations, but as the raw materials of the law. We had no casebooks, nor are there any New Zealand casebooks. Since my return, and while I proceed with the preparation of a casebook and materials, in first of all administrative law, I have done what probably most of you would regard as impossible - used a case method without casebook or materials. I have done this by giving classes cases or materials orally, proceeding thereafter to develop these in class, much as you would. Second, we have started work on a law review to give our students the very valuable training it gives yours and for which I value it; ours will be a modest intramural affair for some years. Third, there are borrowings in moot, library, placement, class gifts, and so on. On the substantive side in my own special field of administrative law, to go no further, what I saw has suggested not only new methods but at least one very important development in scope and has clarified my ideas on the range and the successive steps to be taken in research in New Zealand in this field.

The clearest trait of the American law school we from abroad carry away is that of an institution - faculty and students alike - alive and full of the glory and value of law and lawyers, where law has captured the intellect and the imagination, and become the life of all. This comes as an inspiration to the visitor.

I am indebted to your schools for their "technical assistance" and for their inspiration but - I dare say it despite Saint Benedict - do not imagine that we are entirely on the wrong track back home. I have mentioned New Zealand developments directly resulting from my visit, lest when I respond to the spur of my friends' invitation, you take me for either an ingrate or a carping critic.

Now there is not much use in my merely telling you of the many advantages of case method, or of its scientific basis (if it has any), or of current criticism of it; it was valuable for me to find out these things, but you know ever so much more about them than six busy months could reveal to me. My own conviction, soon came to, that Redlich had built his work on false premises warns me off any flights of this sort. Still there were some aspects of 
your work that I found it difficult to assess and difficult to get others to assess and perhaps on these I might bring an outsider's impressions to you.

I have never really had any doubts about the superiority of case method to lecturing. At its best, and to some extent even at its worst, case method involves a joint enterprise in discovery by teacher and student. That is its great educational achievement. Relatively the lecture leaves to the teacher all the discovery, to the student passive reception.

What American teachers might not realise is that case method has a greater value in teaching practical legal skills with us than it has even with you. Our method of presentation of argument in court is not by written brief but oral from start to finish. In our day in court the analysis of cases, very closely along the lines pursued in your classes, is of the essence.

Of course I know - I learnt it quickly - that there is no one case method. Nor, and American teachers have still to learn this, is there only one lecture method. There can be and are quickly developing not only many variants of each method - as many as there are good teachers - but combinations of the two methods with many and varied emphases. In fact I found that American teachers used the phrase "case method" with different and contradictory meanings; some, being more conservative, used it in contrast to the lecture and regarded many newer methods as but case method variations; others being more radical, contrasted it with the same newer methods and condemned it as failing by comparison. I use the term to include the newer variants.

\section{DECLINING INTEREST IN SECOND AND THIRD YEARS}

So I came to observe case method after using methods tending toward it and already convinced of its value. Immediate reaction on visits to classes was that students found it exciting and that it developed intellect - quick, ready, and eager intellect - as well as interest. This impression is as firm now as it was when I first visited a class - in the University of British Columbia. But I gradually realised, at first with something of surprise, even shock, that students made it clear that they were bored with it; and they meant what they said. Had I made a mistake? Obviously I had to settle this apparent - perhaps real - contradiction for myself. And there were not wanting American teachers who would have liked to turn their backs on case method and who were prepared to advise me never to start it. I think they were wrong.

Now I have no doubt about the prevalence of the boredom; it was constantly commented on by teachers, and students were even more forthright. And there could be no doubt either that the students put it down to class methods. I generally took the opportunity of talking to students and can well remember the advice of one at Columbia to take no notice of what any student said in class, "it was just a waste of time listening to them". One of the best students at Yale went the whole hog - he wanted to see the way the mind of his teacher worked, found 
impassable barriers to this in case method, and asked for lectures. I could not dismiss this dampener with a shrug of the shoulders.

There are no doubt many and varied causes of this boredom or lessening of interest, but I am sure the basic cause lies outside methods of teaching altogether. My reasons? Boredom in students is first of all not a problem peculiar to those taught by case method. It is not confined to the United States by any means, nor in the United States is it confined to law schools. As a student I was subjected to lectures and admit to having been bored by them especially in the later stages of the course. So when I spoke to American students I suggested to them that all students tired of existing methods and wanted a change. They remained unconvinced. Now I grant that case method is one which makes a greater demand on the student and will tend to tire him sooner if he has a tendency to tire, and that boredom will result. And no doubt the brilliant student finds it tedious to listen to the inexpert meanderings after truth of his less talented fellow students. Patience is not inexhaustible and is not a pronounced American virtue anyway. But I am sure I am right when I say that it is not case method which is the basic cause of the boredom.

\section{VARIATION IN TEACHING TECHNIQUES}

I would have been more easily convinced that case method was the cause if I had not been impressed with the variety of method used. American teachers, in fact, having worked out and developed the best known method of lawyer training have not let themselves rest on their laurels: the flagging interest of students has been a challenge; and no teacher who has once awakened lively interest in his first year students could ever sit by and let that challenge go. Search for ever better methods has resulted, and the search has been remarkably successful. A powerfully accelerating, if not the motivating, force behind the introduction of the newer teaching of practical skills - advocacy, counselling, writing, drafting - is the determination of good teachers not to let interest flag. Problem methods, whether the kind only slightly varying case method, or the kind based on large firm preparation for counselling, or the functional course, show the same motive. Professor Leon Green has recently commented ${ }^{1}$ on the need to integrate the whole curriculum, to build the work of later years on earlier, and to reflect developing complexity of materials with methods of greater complexity, and ascribes flagging interest to absence of this integration and accompanying complexity. What he asks for is in fact the development of an existing trend. The splitting up of large classes, another trend seen everywhere, is in the main a reaction to too long adherence to case method and eliminates one of the major student criticisms of it. The changed and still changing casebook itself, its inclusion of more and more statute, text, and notes, is significant and in the same direction. The tendency to write 
textbooks of a size to meet student need and beyond doubt the tendency to admit to a little lecturing - and to do a great deal more than is admitted - are likewise significant. All these have lessened and in large measure were meant to lessen student tension and to widen and thereby to sustain interest.

The developments I have dealt with have been spurred on by the need to create and maintain interest which tended to flag, but of course they are good in themselves - I have not meant to infer otherwise.

I count myself fortunate to have happened upon the case method scene just when it was under fire and just when it was being varied and supplemented. I shall not forget the need to vary and supplement. But I do not delude myself into believing that variations of teaching methods will cure student boredom. It has more important and more elusive causes than teaching methods.

\section{THE LAW REVIEW AND SUCCESS}

One important cause is that far too early in their law courses too many students know that, relatively, they have failed. Even American novels equate success in law school with "making the law review", and so do attorneys. If the review men are chosen on merit in their second year, and those chosen so early will on graduation get the best jobs legal practice has to offer, there must be much discouragement to those who have missed out. In fact the discouragement is quite noticeable. Quite significantly too, boredom develops in the second year. No efforts to give to all students some of the educational benefits of review writing, however valuable in themselves, can make good the damaged morale caused by failure to make the editorial board. It was evident to me that discouragement was the greater, the greater the selectivity for admission to the law school; hopes of success were higher and disappointment at relative failure greater. And there is really no way to fight back.

Evidence of the correctness of this diagnosis is I think to be found in growing student resentment of the law review. Significantly this has shown itself most clearly at Yale where the selection of students has been on the most exacting basis of all. Students at Yale, both those on and those off the review, tended to brand it "undemocratic" - meaning of course that they disapproved of it. Now it is not difficult to see that the law reviews have succeeded because of the strong sense of corporate responsibility of a board of editors who have a keen sense of the honour of, and of the substantial rewards to come later on from, being selected. To make the review "democratic" would secure neither the quantity nor quality of work now achieved, and would I think make it impossible to carry on reviews at all. If the choice lies between review and its attendant discouragement and either no review at all or a much poorer one, I must say that I am on the side of the present review system. Of all the palliatives I saw in operation in the United States I like best the idea of an intramural review - a second review publishing short articles by any student contributor on the basis 
of merit in the contribution and on nothing else. But it did occur to me when talking over this problem with your students that much good might come from making a few places on the review available to students who had previously not "made" it but had demonstrated in their later work in the course that they were the next best offering. The chance that despite earlier failure one might still "make" it would sustain the interest of quite a few students. But perhaps you do this already in some law schools.

\section{POSTPONEMENT OF ADULT LIFE}

I feel sure that an even more basic cause of boredom than the discouragement deriving from relative failure prematurely fixed and determined, results from the lengthy postponement of the beginning of man's economic life involved in the law course and its prerequisites. Complaints I gather have swelled with the influx of veterans, obviously men and women kept at school to an even greater age than other students. The problem is one posed by the growing length of modem education in professional fields. We teachers are prone to think of just how much we can do if we have students for longer; there is so much to do. We forget the psychological toll that postponement of adult activity involves. No doubt that toll is accentuated by repeating in the second and third the methods of the first year, because this frustrates the desire to leave that first year behind. No doubt the developed variations of method in the later years of the course serve the very important purpose of lessening the psychological toll. The toll remains all the same.

\section{INTEGRATION OF ARTS AND LAW}

This leads me to some comment on integration of law and arts. I pass over teaching of economics, philosophy, etc, within the law school, with particular emphases for the benefit of lawyers; these courses were an interesting integration even if of varying success and precarious tenure and, of course, a very great luxury. I am concerned here only with prelegal arts work. I asked myself whether there could not be better integration of arts and law involving an overlap and possibly a shortening of the length of the combined courses.

I can see that there are some ways in which the organisation of the American university retards integration of arts and law work. The American university tends to be a loose confederation of independent schools, where the traditional British pattern is of mone closely knit faculties forming a unit. It is far easier for us to fuse arts and law. Our law course in fact assumes an overlap of work in arts and law. I believe you lose something quite valuable in drawing the firm line you do between pre-legal and legal education, between college and law school, between arts and law. It seems to me that your students would gain a good deal by taking some law in the third and fourth years of their arts course and by carrying over some arts into the first two years of their law course. The lawyer in his training needs constant reminder that there is a larger world back of the law which he will fail to understand only to his very great detriment. For this very reason arts work will 
be apt to mean more to the lawyer if he is forced to some of it while studying law. Conversely law will tend to be more than mere law. Our own experience indicates that a healthy interest in both arts and law can be sustained concurrently, with great value to each. Our students are required to take about half an arts degree as part of a five year law course. Normally the arts units are taken in the first two years, but an increasing number of students take further arts units in their third year, and one of the more brilliant of those who did this recently completed his course as quickly as those who took the ordinary course. I am sure that well selected groups like your law students could get as good results with a shorter but more intense overlapping arts and law course. My experience of students here is that arts and law take concurrently enable more of each to be handled more quickly and to better purpose. From my own personal experience, I know that the most rewarding year's study I did was one in which I took Constitutional Law and Roman law for a law degree and the final year of an Honours Course in English for an arts degree. Such a course might get lawyers to work earlier and give the student more variety.

\section{LARGE AND SMALL CLASSES}

I have mentioned already the move to break up large classes in the later and sometimes in the earlier stages of the law course and would like to return to it. I cannot see that case method is at its best with large classes. I know and naturally respect Dean Griswold's opinion to the contrary, but I remain unconvinced. If you will accept so emphatic a statement from a wayfarer among you, there were in large classes far too many students who simple answered, "Not prepared". "Not prepared" ruins case method. It is, I think, a consequence of large classes, for if the chance of being called on is only one in fifty, why not take a chance, as far too many do. And I imagine that if you do prepare your work consistently and are not called on for weeks, enthusiasm for preparation must wane. Case method demands, I can see, constant and active participation of every student, but you can't say your say every class hour if you are one of a hundred and fifty or more. I don't mean that case method fails with large classes; you have a number of very brilliant teachers to make it succeed even in large classes - hours I spent listening to Seavey, Sturges, Cheatham, Fuller, and Leon Green, to name but a few I was fortunate enough to hear in action - leave me in no doubt of this. Still when I subtract the brilliance of the teacher and then compare the small with the large class I am convinced that case method is made for small classes and is subjected to considerable strain in large classes. I am comforted anyway in the knowledge that Langdell's classes were about the same size as those I am likely to teach in my early years of case method. And I do not propose to acquiesce in the answer, "Not prepared".

I don't know whether law teachers realise to what extent students do not hear what other students say. Case method demands that they hear everything. Some teachers did deliberately see to it that everyone heard, but most had apparently given up the unequal effort. Your classrooms strangely enough are constructed for the lecture method; there has 
been till very recently scarcely any coordination of architecture and case method, and even now, of all I saw, only two new buildings at schools in California have what they assure me will be the answer. I suppose I have attended classes of more law teachers than any of my readers and believe me this is an important matter; a great deal of good work is rendered ineffective because with a method of tuition which asks for integration of all that goes on throughout the hour, few members of the class have even heard everything said.

\section{LECTURE}

Before I leave methods of teaching I should say something about lecturing. As I have said, I have no doubt that case method is better than lecture. But I would use both. The lecture has its value. I rather think you should reexamine the lecture and not condemn it unheard. My general feeling is that it is exiled from avowed use as the enemy which the better schools fought and conquered, conquered only after emotions were thoroughly roused; no one can, even now, use it without suspicion of having gone over to the enemy. But the enemy has been dead for a generation and the lecture can surely now be more dispassionately explored.

On quite a few occasions I heard American teachers give lectures or addresses out of class and, if I had had any doubts about it, they showed me clearly enough that they could lecture ably. But resort to lecture in class always involved a let down in interest and tempo; you will, I trust, exonerate me from any suspicion of boasting when I say that I am sure I do, whenever I lecture to a class, easily get and maintain more interest. The contrast anyway between interest evoked out of class and failure to interest in class surprised and intrigued me The first and primary cause of the failure is the conscience-stricken feeling American teachers have that in lecturing they are being driven to an inferior method, a feeling difficult to escape when it is shared by students. I think it is a very great pity that conscience robs the lecture (in class) of value.

A second cause of failure is the use of the lecture to save time. Don't be under any illusion that good lecturing saves time. If, of course, all that the lecture does is to toss off a lot of information which is swallowed by the student's pencil and notebook, it can make many points quickly. But that is not a lecture at all. A lecture on the one hand may, like Maitland's Lectures on Equity, unfold a fundamental idea gradually, clearly, and exhaustively, so that it cannot but be understood. Its value is to demonstrate how ideas are clarified, systematised, and made clear to the uninformed - incidentally as valuable a technique as any lawyer can ever acquire. Why not provide the student with a demonstration of clear, understandable expression of ideas? I would go further and encourage the student also to express himself in the same way in class. In fact one criticism I have of the case method, as practised more particularly in the early years of the course, is that it does not give students any training in presenting an argument or idea, or point of view with any sort of completeness; it relies on the cut and thrust of short question and 
answer. Of course he has his moot, but he needs more chance to develop his ideas more fully in class too. I have it in mind anyway to try to develop some lengthier exposition of their views by students in class. Alternatively the lecture can carefully and adequately unfold a problem in all its ramifications and in all its complexity, just as case method does. I like to lecture in this way. I don't think that lecturing is a less valuable educational tool than case method because it fails to awaken or sustain interest in a problem. The real superiority of case method lies not in a monopoly of power to excite but in the active positive exploration of the problem by the student, as compared with passive reception through lecture.

History and theory notwithstanding you are using more and more lecturing to qualify case method; we now use more and more case method to qualify the lecture; the difference between us may already be one of degree and quite likely we are each tending pretty much to common ground. But do have a look at the lecture a little more objectively.

\section{CURRICULUM}

Your curriculum interested $\mathrm{me}$ in several respects. Like you, we aim at giving fundamental courses, building more specialised courses on these and then adding courses of broader public significance at the end. I was interested in the inclusion of legal method and procedure among the fundamental courses. On legal method we have been content with an introductory set of hints and the force of example dinned home later in the fundamental courses. It may seem to you inevitable to take procedure early. We teach it late in the course, for a quite definite and, you have persuaded me, quite wrong reason - ie, the leaving of a course till the student has had the benefit of practical experience to make it easier for him, whereas sound teaching requires that a course be put where it necessarily contributes most to the student's understanding of law. Procedure taught late in the course is a mere learning of rules, of little or no pedagogical or training value, rightly condemned but not easy to eliminate against professional opposition; at the beginning it could be and is an interesting and enlightening discipline, of enormous value in the study of all other subjects. Case teaching will certainly force it to an earlier place in our course. The place of public law in the curriculum in particular the move (which I first saw at Columbia and then at many places) to place some public law among the fundamental subjects, commended itself to me I would not agree with the view expressed by Professor Morris in the Harvard Law School Bulletin that there was too much public law in American legal education. I formed the opposite impression, that there was too much emphasis on private law and that public law was still not as well integrated into the curriculum as it should be. Constitutional law taken in the first year will do much to correct this and make it easier and more natural to the student to turn to more public law in his second year and in turn to get more out of the more broadly based work of his third. I have noted the development in first year for use in New Zealand later. 


\section{OFFICE EXPERIENCE}

One of the most far-reaching differences - perhaps the basic difference - between your training and ours is concentration for some years on law school work to the exclusion during those years of practical experience. I must explain the New Zealand position here partly because explanation is necessary to the understanding of what $I$ have to say and partly because it was not accurately put when dealt with in your Survey of the Legal Profession.

We distinguish in the New Zealand university between full-time and part-time students as do British universities. This distinction, however, does not exactly correspond to your distinction between day-school and night-school. Our full-time student is so classified because he is engaged in university work to the exclusion of all other work. Your day-time student may engage in outside employment so long as he can get to class and do the necessary work. At Victoria University College we have in our law classes a mixture of full-time and part-time students. Full-time students predominate in the early years, part-time in the later; we deliberately encourage students to do their first two years full-time and their final three years part-time, and most of them take our advice. Almost all our part-time students work in law offices, either private practice or government. The noticeable feature of your night schools was that the students were seldom if ever working in law offices at all. This and their lecture hours completely differentiate your night schools from law schools in New Zealand. Our law lectures are given from 8 to 10 am and from 4 to $6 \mathrm{pm}$, with one subject now given in the middle of the day. Your night school students moreover were a much older age group than ours; our part-time students roughly correspond in age to your day-time students.

Even at the risk of the sanctions threatened by Saint Benedict I remain obdurate in preferring this mixture of school and practice to your system.

Most law students attending daytime classes in the United States do devote full-time to their university work for from one to one and a half years. But, to an extent I did not realise for quite a while and to a far greater extent than most (not all) United States law teachers realise, your students in their last two years, and especially the last year, take on considerable hours of outside work. They do this without failing, often making good grades. In some good state university law schools I was told by quite reliable sources the percentage of students in the final year working was certainly as high as 70 per cent. It was probably higher. In even the best law schools it was admitted to be from 10 to 15 per cent, and was probably higher. Now there must be a percentage of any class beyond which you cannot go if the work of the class is not to cease to be that of a class of full-time students (in our sense) and become a part-time class (again in our sense). From my own experience of working with mixed groups of full and part-time students I would put at no more than 35 the percentage of part-time students which reduces the quantity of work a class actually does from the full- 
time to the part-time level. This means that all but a very few United States schools have what we call part-time classes in their final year, and a very large number are in the same position in their second year. I hadn't expected this. Some schools have recognised the problem and made provision to extend the length of the course of their part-time students Northwestern springs to my mind as one school handling the problem realistically.

In some few instances - Wisconsin was an example - a percentage of students working, particularly in the final year, were getting experience in law offices; I was told it was difficult to provide classes in options in the afternoon for this very reason. Mostly, however, the students worked at anything but law. Now in America you have been used to a situation where a man either attended a university or was apprenticed. You have pretty nearly put an end to apprenticeship and secured a very great increase in university training - but to a considerable extent you have substituted the garage and the eating place for the law office. On the other hand we have worked out a system where every student is required (not merely given the chance, but required) to take a university course and where nearly all get office experience during that course. If law students are to work, I prefer to see them work at law and get practical experience which, whether necessary or not to practice on graduation, is valuable. But in any case I would prefer to see them get practical experience during their university law course.

Several further comments are necessary to clear up and round off the picture I have given. The first is that for the purpose of gaining experience the lot of the unqualified, but qualifying, law clerk in New Zealand is probably better than it is anywhere else in the English-speaking world. We have a shortage of both qualified and unqualified law clerks, and the unqualified student has a scarcity value in the market. He is not apprenticed and can see to it that he gets experience. He cannot be regarded as sweated labour. Some readers may know something of our compulsory arbitration system with an Industrial Arbitration Court settling conditions of employment by "Awards" in the event of disputes between employers and employees. The law clerks have their union and an award. The wage, though not of course as high as law students think it should be, is greater than you would associate with the remuneration of articled clerks, enough anyway to force an employing attorney to give the student fairly responsible work. From the point of view of efficient training this situation is pretty satisfactory. But student numbers are on the increase; if this trend persists, or if the student's wage is pushed up beyond his economic worth, we may have an end to concurrent school and office experience. But I insist I do not want to see this happen.

It is probably fruitless to discuss whether without prior practical experience a man is fit to start practice on his own on leaving law school. With you the question does not arise for those who go into large city firms for they are trained there and not at the expense of the public. I suspect that as to those who start practice on their own that being a practical 
individual may be more important than practical experience, though the latter can scarcely be anything but a helping hand. I tried to secure the views of both teachers and practitioners on office experience. Teachers were apt to think practical experience unnecessary because they had in mind many examples where calamity had not followed. Practitioners seemed to be pretty much divided into two camps, the older and the younger. The older favoured a compulsory but generally short span in a law office; mostly I thought more nostalgia than a smoke screen to secure economic benefits. The younger had mostly started straight from law school themselves and were not in favour of a term of practical experience. The majority answered any query on this issue with a simple statement that they did not want unqualified men; they were only interested in those who had qualified. Their view seemed to me to have prevailed and was underlined by the soliciting which law schools, like Northwestern, had to undertake when they wanted to place students in offices to give them practical experience.

I have never thought that the argument for practical experience turned on the impossibility or near impossibility of commencing practice on your own without it. But I believe it has two very great virtues. The first is that it makes much more real the work in the classroom and so gives a different quality to all student work; it is for one who has experienced for himself actual clients with actual problems that law lives. I gather that many of you would agree with this. If this is so it follows surely that that sense of reality should be got early in the student's course. I think we manage to secure this result. The second important result we achieve is a smooth transition from law school and books to practice. To take advocacy as an example, most of our students have already handled some matters in chambers and learned to cross swords with the other side and to speak to influence a judge and not just to argue before they are half-way through their law course. And the course is so organised that many in fact qualify to practice in the lower courts with still another year (academically a light one) of their course to complete. So that they are actually practising in their final year. The student grows as an advocate - as a practitioner - while he tapers off his studies.

Substitutes for this sort of practical experience which United States law schools are trying to develop do not seem to me to promise adequate returns. Legal aid clinics are a valuable adjunct to teaching and a very valuable reminder of the public duty devolving on every lawyer to see that all get justice. Yet (and ignoring the fact that legal aid promises little to our students for there is practically no scope for such aid in New Zealand) I remain unconvinced that it does have the value of normal office practice. It is not, and is known to the student not to be, the sort of practice he is going to have; it is too limited in range of work to be done; one is being charitable and not making one's living; and my own experience - I did some legal aid work in early years of practice in Australia - is that the cases are too often discouragingly poor legal material. I don't suggest, even if it were not presumptuous of me to do so, that law schools give up their legal aid clinics. I admire the work being done so much 
that we are in fact exploring the possibility of some legal aid work here; and clinics are an important and valuable public work, and give some valuable practical experience. I am only emphasising, what I suppose is obvious, that actual practice is far better practice than legal aid work ever can be. The other substitute is to arrange for students to have, as it were, a few hours of practical work a week in an office. This was valuable evidence, I thought, of the anxiety of the schools, who were concerned at lack of practical experience. All the same it seems to me to be of little use. You need to be in an office continuously - I would say for at least two months on end - to get the continuity which allows you to handle matters satisfactorily. Legal work won't wait till you turn up for your practical work next week. A few hours a week are not enough anyway. Some but not many students did take the opportunity their long vacation provided to get into law offices, and they spoke enthusiastically of the value of their experience.

The argument against work in an office I heard most often expressed was the time factor. There was so much a student must be taught that he must be kept full time at law school. But this argument assumes that the student can only cope with his law course if kept at law school full time - an assumption which in very many law schools is not well founded and neglects the obvious fact that law review editors work long hours on the review and still cope with the course, in all law schools. Surely, too, we are all over-anxious about the bulk of the law which we insist that a student must know. We have added and added (we seldom manage to subtract) till the bulk has become unwieldy by any standard. In the same way I heard departure from case method either advocated or deplored because forsooth it took up too much time. If ever there is a putting of the cart before the horse, it is this one. The content of your courses - and of ours - needs very serious overhauling. We insist that we cannot teach all the law, not even all the law in any subject we do teach. The very essence of teaching is selection, the introduction of a student to some materials on which he himself will have to build or which will indicate to him ways in which he can handle other materials. I would certainly not depart from a recognised best method of teaching for lack of that good healthy pruning which is my answer to warnings given me that case method is wasteful of time. Nor would I give up the solid advantages of practical work in an office merely because it meant that I reduced the quantity of law covered in class. I expect less law, taught by case method, to mean more than more law handed out in lectures. And I likewise expect the lesser quantity covered by a student working in an office to mean more than the greater quantity covered by a full-time student. Teaching is a matter of balancing many factors in training, only one of which is content.

Expressing this view I was from time to time challenged to say how I would implement it in America. If the majority of teachers oppose a term of office work because of the time factor and because of its sweated labour history and background, and if whatever the organised bar, may wish, the majority of practitioners would not employ students, our system is quite clearly out of the question. Moreover, the very fine work done by your law 
schools in training people for walks of life other than law complicates the matter to no small extent. The best I can with all diffidence suggest is that law schools insist on a total of six months' full-time office experience undertaken not before the conclusion of the student's first semester and not later than the commenoement of his second year. That six months would add to the value of law school training. And I rather think a further period of six months' training in an office, undertaken not earlier than during the final year of his course, should precede practice by the graduate on his own account without partners.

Before I bring this already too long discourse to a close let me make some comments on two further matters.

Your law course is many generations removed from the bread and butter course but to an outsider it still seems to need more of the orientational and jurisprudential. This you are well aware of, and the long strides made at Harvard, for instance, to overcome it, make it more than unnecessary to pursue the matter. I was interested, however, in the possibility opened up by methods which I saw most clearly and forcefully in the classes of Professors Fuller and Leon Green and which I would describe as a bringing down into the practical subjects of jursiprudential material. It was more than a bringing down of judicial techniques, it was an invitation to the class to see in this problem now dealt with some fundamental trait of law itself or of the way of the law. After all, if the problems of jurisprudence can be concretised in the cases dealt with in practical subjects, so that the teaching of the practical and the jursprudential become fused, we will have something better than the learning separately of jurisprudence and contracts (or any other practical subject). If your late attention to jurisprudence leads to this fusion then it has been a fortunate retardation. The traditional British separation of jurisprudence and practical subject has, I think, meant a greater emphasis on jurisprudence, but a singularly unsuccessful effort to give jurisprudence any reality in the eyes of students. You seem to have in the past given it less attention but more reality, and present trends should greatly enhance attention and reality. The new Readings of Cohen and Cohen show the way.

The other comment is the voicing of a feeling that the newer techniques emerging to a subordinate but firm place in teaching today - problem method, the functional approach, counselling, drafting and writing programmes in particular - will ultimately transform case method to such an extent that a new method will take its place. They are based on the assumption that case method is wanting and so in a sense it is. The lawyer is faced with problems and has at his disposal a library. We should, if we could overcome the mechanical difficulties, teach the student throughout this course by requiring him to solve problems by using the library. The fictitiousness of case method lies in the habit of working from a casebook, in deriving law from the cases in the casebook, even deriving the problems to be solved from the casebook. The student should be taught his law by solving problems, drafting documents, counselling, and so on, and should become less and less dependent on his 
casebook. This is where you seem to me to be heading and it will be very interesting to watch the developments of the next ten to fifteen years. 
(1999) 30 VUWLR 